\title{
Malice as an Ingredient of Tort Liability
}

\author{
John Murphy*
}

\begin{abstract}
This article is concerned with the question of whether malice is an appropriate touchstone of liability in tort law. It begins by identifying four torts in which malice may properly be regarded as an ingredient of liability (distinguishing various other torts, such as private nuisance an defamation, in which malice plays a merely secondary and contingent role). Having identified these four torts - ie, malicious prosecution, abuse of process, misfeasance in a public office and lawful means conspiracy - the article then seeks to identify a common juridical thread which links them together. So doing serves to rebut the allegation, often made in respect of all them, namely, that they are anomalies actions. It then concludes by considering the individual worth of these torts, bearing in mind the important difference between not being anomalous on the one hand, and being positively meritorious on the other. It concludes that a respectable defence of each of the four torts can be made even though malice is an atypical touchstone of liability.
\end{abstract}

\section{Introduction}

Malice plays a part in the imposition of tortious liability more than is commonly recognised. This lack of recognition is due partly to the fact that those torts in which it fulfils this role are seldom taught in university law schools, and partly to the fact that they are relatively rarely encountered by practitioners. True, the role of malice in a handful of nuisance cases is well known, as is the way in which it serves to defeat a plea of qualified privilege in the tort of defamation. But the torts in which malice functions as an essential ingredient of liability are anything but standard fare. For reasons that will become apparent in due course, it is hard to be certain just how many such torts there are. But I shall argue that there are four clear cases: malicious prosecution, abuse of process, ${ }^{1}$ misfeasance in a public office and lawful means conspiracy.

The relative paucity of academic engagement with these four torts cannot be explained purely in terms of their being seldom taught in law schools and rarely encountered in practice. Another significant factor explaining their relative neglect by (or lack of attraction for) jurists is the fact that they are typically regarded as anomalous actions. ${ }^{2}$ All four of the torts just named have been described in such terms by jurists or judges or both over the years. Yet these allegations are unconvincing for several reasons. First, they are typically made by way of bald assertion, ${ }^{3}$ which ought always to raise

\footnotetext{
* Lancaster University. I am grateful to Peter Cane and Nick McBride for their comments on a draft. Thanks are also due to Roderick Bagshaw and William Lucy for informal discussion of some of the issues discussed in this article.

${ }^{1}$ It is arguable that this tort can be divided into two: cases in which D maliciously initiates legal proceedings in the strict sense, and cases in which D maliciously instigates a process short of this, eg, maliciously procuring an arrest warrant (Roy $v$ Prior [1971] AC 470) or a search warrant (Gibbs v Rea [1998] AC 786). Either way, they are different. The latter (but not former) tort requires D's initial action to have been abandoned or to have ended in C's favour before it can be invoked. 2 One exception is Arthur Ripstein. He, however, fails to distinguish those torts in which malice plays a secondary and contingent role, from those in which it forms an essential ingredient of the action: see A Ripstein, Private Wrongs (Cambridge, Mass 2016) ch 6.

${ }^{3}$ See, eg, WE Ormsby, "Malice in the Law of Torts" (1892) 8 LQR 140, 149: "[t]he cases in which [malice is essential are] ... exceptional, and ... anomalous"; E Chamberlain, "Misfeasance in a Public Office: A Justifiable Anomaly within the
} 
doubts about credibility. Secondly, those who cry "anomaly" give no indication of what the benchmark is against which such an accusation may be measured. Since torts are highly heterogeneous - in terms of their liability bases, ${ }^{4}$ their remedies ${ }^{5}$ and their structure ${ }^{6}-$ it is far from clear what it might mean to say that a tort is anomalous. Thirdly, even supposing that the benchmark is some or other theoretical understanding of tort law (and the torts in question are described as anomalous because they clash with that theory), it by no means follows that we should afford great weight to the claim that they are anomalous. It is one thing for a senior, appellate court judge to describe a rule of law as an anomaly, but quite another matter if the claim is made purely by a jurist. Put otherwise, jurists who produce grand theories of tort are sometimes minded to say that tort $x$ is an anomaly simply because it does not fit their theory. But this does not mean that we must accept that tort $x$ is an anomaly because it clashes with a certain theory when it has been endorsed repeatedly at the highest judicial level. ${ }^{7}$

Without any clear idea of what is meant by "anomaly", we are left only with the vague suggestion that these torts are all unusual in some unspecified way. Perhaps it is thought they are aberrations: torts that are unnecessary and which should never have been created? Perhaps it means no more than that they are each, for some or other reason, unique? But what if they are not anomalous in either of these ways? What if, taken together, they form an important and possibly growing subset of tort law? If that be so, then there is a strong case for seeking to understand them better; to work out why malice forms a touchstone of liability within them bearing in mind the fact that, since Allen $v$ Flood, ${ }^{8}$ it has generally been thought that malice is not a suitable peg on which to hang tortious liability if the act in question is not otherwise wrongful.

That the four torts just named cannot seriously be thought to be anomalous in the first of the two senses mentioned is easy enough to show. Each of them has had its vitality confirmed by our most senior judges in the last twenty years or so. The misfeasance tort and lawful means conspiracy were both fortified - perhaps even rescued from obsolescence ${ }^{9}$ - by landmark decisions of the House of Lords in the first decade of the twenty-first century. ${ }^{10}$ Malicious prosecution received a significant boost when, in 2016, its scope was extended ${ }^{11}$ to cases of the malicious pursuit of civil actions in Willers

Rights-Based Approach?" in D Nolan and A Robertson (eds) Rights and Private Law (Oxford 2012); Lonrho Ltd v Shell Petroleum Co Ltd (No 2) [1982] AC 173, 188 “conspiracy is a highly anomalous cause of action” (Lord Diplock); Crawford Adjusters Ltd v Sagicor Insurance Ltd [2014] AC 366, [145]: "malicious prosecution is in modern conditions an anomalous tort" (Lord Sumption).

${ }^{4}$ The liability bases of torts vary from strict liability to torts requiring intention. Yet others require fault of a kind that falls short of intentional wrongdoing.

${ }^{5}$ Various, relatively rare remedies - such as quia timet injunctions, gain-based damages, aggravated damages and exemplary damages - are available in tort law. Furthermore, they are sometimes available in respect of a handful of torts when the the usual tort remedy of compensatory damages is not available. For a full exposition of the remedial heterogeneity of tort law (and the absence of a default remedy which unifies torts), see J Murphy, "The Heterogeneity of Tort Law" (2019) 39 OJLS (forthcoming).

${ }^{6}$ Most torts are bilaterally structured. Some economic torts require that $\mathrm{C}$ strike at $\mathrm{D}$ by committing a civil wrong against an intermediary, T. These torts include the unlawful means tort, malicious falsehood and passing off. Dependency claims under the Fatal Accidents Act 1976, claims under the Congenital Disabilities (Civil Liability) Act 1976 and claims against employers based on vicarious liability, all fit this tripartite structure, too.

${ }^{7}$ For a trenchant attack on theorists who with little reflection condemn as anomalous or wrong appellate court decisions, see J Stapleton, 'Taking the Judges Seriously' https://ox.cloud.panopto.eu/Panopto/Pages/Viewer.aspx?id=c43ce0fc7623-47ec-a1e8-a8cf0099a581.

8 [1898] AC 1.

${ }^{9}$ See, eg, Davis v Bromley [1908] $1 \mathrm{~KB}$ in which the Court of Appeal denied the existence of the misfeasance tort.

10 See Three Rivers DC v Bank of England (No 3) [2003] 2 AC 1 (misfeasance tort; House of Lords); Revenue and Customs Commissioners v Total Network SL [2008] 1 AC 1174 and JSC BTA Bank v Khrapunov [2018] UKSC 19 (lawful means conspiracy; House of Lords).

${ }^{11}$ Lord Toulson was clear that the question before the court was whether "the [existing] tort of malicious prosecution includes the prosecution of civil proceedings" (italics added). Cf J Goudkamp "A Tort is Born” [2017] NLJ 11. 
$v$ Joyce. ${ }^{12}$ And its sibling - abuse of process - was also regarded by the Privy Council as an extant tort "distinct from malicious prosecution" just a few years ago. ${ }^{13}$ On the basis of these decisions, each of these actions can defensibly be said to have a proper place in the modern compendium of torts. Such weighty judicial endorsement certainly undermines the idea that they are on the wane, and probably also undermines the suggestion that they were erroneously created in a bygone age. ${ }^{14}$

The claim that they are anomalous in the other sense - that is, unique causes of action - is not so easily rebuffed. True, there is an obvious link between abuse of process and malicious prosecution, but these two torts have no obvious connection to either the misfeasance tort or lawful means conspiracy (which torts, in turn, have no apparent connection with each other). If there is a link between the four torts, then it lies beneath the surface. This article seeks to excavate that link. It aims to show that they share a common conception of malice, ${ }^{15}$ and that this conception of malice explains their raison d'etre.

Part II of this article is prefatory. It explains why only the four torts highlighted need concern us even though they are not the only ones in which malice can play a dispositive role. More particularly, it suggests that within the four named torts proof of malice is always required in order to substantiate a claim whereas in other torts its role is both contingent and subsidiary. Part III aims to unpick the various conceptions of malice found within the four torts over the last few centuries and to distil from among these a single, common, modern conception of malice that may plausibly be said to be at work in all of them. So doing has the merit of showing consistency in the law. ${ }^{16}$ Part IV attends to the most important issue of all: the normative question of whether malice ever ought to ground liability in tort. Part $\mathrm{V}$ draws things to a close with a number of concluding remarks.

\section{Torts in which Malice is a Necessary Ingredient}

As the name of the tort suggests, malice is crucial to the imposition of liability for "malicious prosecution". In addition - although the need for malice is sometimes expressed via various synonyms - the general view is that malice also comprises an essential element in the torts of abuse of process, ${ }^{17}$ misfeasance in a public office and lawful means conspiracy. In all four actions, malice may fairly be described as a discrete touchstone of liability, although arguably this is only obvious in the case of malicious prosecution. ${ }^{18}$ In the other three torts, the fact that malice is an essential ingredient requires some unearthing.

\footnotetext{
12 [2016] 3 WLR 477.

${ }_{13}$ Cranford (n 3) [62] (Lord Wilson).

${ }^{14}$ It is in theory possible that they were not needed when originally created, but that they have become necessary since. But there is no hint of this in any of the cases.

15 Most writers who have tackled the meaning of malice acknowledge the confusion surrounding this term: see, eg, FH Newark, "Malice in Actions on the Case for Words" (1944) 60 LQR 366; 366-7; Ormsby (n 2) 140-144; WL Prosser, "Injurious Falsehood: The Basis of Liability" (1959) 59 Col L Rev 425, 428-430.

16 Since consistency is tied closely to the dignity of the law, there is obvious virtue in consistency. Also, such commonality between the torts helps undermine the claim that they are anomalies.

${ }^{17}$ Grainger v Hill (1838) 4 Bing (NC) 212, 224 (Bosanquet J): "[ $\mathrm{t}$ he action is ... for maliciously abusing the process of the court". In Gilding v Eyre (1861) 10 CB NS 592, 604 (Willes J): D liable for having "maliciously employed the process of the court".

18 See, eg, Glinski v McIver [1962] AC 726, 765; Willers (n 12) [54].
} 
In the tort of lawful means conspiracy, the malice requirement is typically expressed in terms of the defendant having acted with the predominant purpose of harming the claimant. ${ }^{19}$ Even so, we will see in Part III why the predominant purpose requirement in that tort can be treated as synonymous with the need to show malice. In the case of both misfeasance in a public office and abuse of process, the malice requirement also requires some excavation. According to the leading case of Three Rivers DC v Bank of England (No 3), ${ }^{20}$ there are two forms of the misfeasance tort. Only in the definition of the first of these is the need for malice spelled out. As Lord Steyn explained, this version is committed where there is "targeted malice by a public officer, i.e. conduct specifically intended to injure a person or persons" with accompanying "bad faith in the sense of the exercise of public power for an improper or ulterior motive". ${ }^{21}$ In the definition of the second form, there is no overt mention of a need for malice. Lord Steyn said merely that, in this guise, the tort is committed by "a public officer [who] acts knowing that he has no power to do the act complained of and that the act will probably injure the plaintiff". ${ }^{22}$ True, he was quick to add that this form of the tort also "involves bad faith". ${ }^{23}$ But it is by no means obvious that his appendage of the need for bad faith was intended to render the second version of the tort one that also required malice. This is, however, how I think we ought to regard it. As was explained in one notable Australian case, the public officer who acts with bad faith has necessarily acted "in the absence of an honest attempt to perform the functions of the office". ${ }^{24}$ And, as Deane J spelled out in that same case, acting with deliberate or reckless disregard for the proper limits of one's powers is tantamount to malice in this tort so long as resulting injury or loss is foreseeable. As he put it:

[t]he requirement of malice ... [is] satisfied if the act was done with knowledge of invalidity or lack of power and with knowledge that it would cause or be likely to cause such injury. Finally, malice will exist if the act is done with reckless indifference or deliberate blindness to that invalidity or lack of power and that likely injury. ${ }^{25}$

Abuse of process is also a tort in which malice is key. But just as with lawful means conspiracy and the misfeasance tort, the leading cases reveal the use of various terms that are intended as synonyms or surrogates for malice. The classic explanation of abuse of process was supplied in Grainger $v$ Hill in which it was said that the tort is animated by a defendant's abuse of "the process of the law ... to effect an object not within the scope of the process". ${ }^{26}$ There, the defendant had sued the claimant for debt (even though the sum owed was not due to be paid for another 10 months). Tindal CJ was adamant not only that the claimant had available "an action for abusing the process of the law, by applying it to extort property from the Plaintiff" but also that this was "not an action for a malicious

\footnotetext{
${ }^{19}$ See, eg, Crofter Hand Woven Harris Tweed Co v Veitch [1942] AC 435, 445. There are a few cases in which the need to show malice has been stated expressly: see, eg, Quinn v Leathem [1901] AC 495, 512 (Lord Shand): "combination ... in pursuit merely of a malicious purpose to injure another would be clearly unlawful".

${ }^{20}$ [2003] 2 AC 1.

21 ibid 191. Cf Ripstein (n 2) 182-3 (seeking to portray the malice requirement in this tort as being about D's means and not D's ends, yet invoking only the rather dated case of Roncarelli v Duplessis [1959] SCR 121 and not the modern definition of the tort in Three Rivers).

22 ibid.

23 ibid.

24 Northern Territory v Mengel (1995) 185 CLR 307, 357.

25 ibid, 370. In this jurisdiction it has been held that "[w] here a Judge of an inferior court, acting within his powers, from corrupt motives gives a wrong decision, malice is the foundation of any action against him": Ferguson v Kinnoull (1842) $9 \mathrm{Cl} \&$ F 251, 321 (Lord Cottenham) (emphasis added). See also the dictum of Lord Clarke in Willers (reproduced below in the text accompanying (n 81)).

26 (1838) 4 Bing (NC) 212, 221 (Tindal CJ).
} 
arrest or malicious prosecution". ${ }^{27}$ Central to the difference, he said, was the fact that in cases of abuse of process, "it is immaterial whether the suit which that process commenced has been determined or not, or whether or not it was founded on reasonable and probable cause". ${ }^{28}$

By contrast with the four torts just considered, malice is not an essential ingredient in two further torts in which it nonetheless sometimes features as a relevant consideration. In both private nuisance and defamation, malice plays a role that is both contingent and secondary. By contingent, what I mean is that the relevance of malice will depend upon the facts. For certain torts, the issue of whether D acted maliciously is not a precondition of liability, though if it happens to be present it will be relevant to deciding the case. By secondary role, what I mean is that malice does not, per se, comprise a freestanding touchstone of liability. It serves only to illuminate whether some other consideration, which is in fact key, has been satisfied. It may shed light on whether a specific touchstone of liability has been met, or it may indicate whether the defendant should be denied a particular defence. ${ }^{29}$

The contingent and secondary role of malice in private nuisance is readily demonstrated. It plays a contingent role in that its relevance in nuisance cases is exceptional, ${ }^{30}$ requiring unusual facts to be present. Indeed, the instances in which it has proved pertinent are - despite their relative fame remarkably few in number. Why, though, do I claim that its role is merely secondary on such occasions? The answer is this: malice has no independent juridical significance in such cases. It is simply a factor that illuminates the genuinely fundamental question of whether the defendant caused an unreasonable interference. In Christie v Davey, North J made clear that he "was persuaded that what was done by the defendant was done only for the purpose of annoyance, and ... [was therefore] not a legitimate use of the defendant's house." 31 Expressed more succinctly, the defendant's malice rendered his user of his land unreasonable (which in turn, and critically, rendered the interference caused to his neighbour an unreasonable one). As Frederick Pollock put it, the fact that one is deliberately annoying a neighbour "may be relevant to show that the defendant is not using his property in an ordinary and legitimate way such as good neighbours mutually tolerate". ${ }^{32}$ Ultimately, liability attached to the unreasonableness of the interference caused rather than the defendant's malice per se. In line with orthodoxy, malice was not treated as an independent ingredient of liability. ${ }^{33}$

Similar analysis can be applied to the role of malice in the law of defamation. It is has a merely contingent role there in that questions of whether the defendant was actuated by malice will only be addressed in a limited number of cases: specifically, those in which a defence of qualified privilege or honest comment is invoked. And just as in private nuisance, the presence of malice has a merely secondary role to play because malice simply sheds light on the genuinely fundamental question of

27 ibid.

28 ibid. Note, however, that in common with malicious prosecution, abuse of process has at its core "civil proceedings brought ... maliciously and without any proper justification": Willers (n 12) [62] (Lord Clarke).

${ }^{29}$ I don't deny that malice may ultimately be the determining factor. My point is merely that malice has no independent significance as an element of the tort that must always be shown in cases of this kind.

${ }^{30}$ See, eg, Christie v Davey [1893] 1 Ch 316, 326; Followed in Hollywood Silver Fox Farm Ltd v Emmett [1936] 2 KB 468. These cases are in no way undermined by Bradford Corporation v Pickles [1895] AC 587, for in that case claimant had no right to receive the flow of water obstructed by defendant. In both Christie $v$ Davie and the Hollywood Silver Fox farm case the claimants had rights to the peaceful enjoyment of their land that were affected by the defendant's malicious conduct.

31 ibid 327.

${ }^{32}$ F Pollock, The Law of Torts $7^{\text {th }}$ ed (London 1904) 400.

${ }^{33}$ Pollock believed firmly in principle that "[e]very one commits a wrong who harms another ... by an act intended to cause harm" (F Pollock, The Law of Torts $2^{\text {nd }}$ ed (London 1890) 52), yet he was forced to admit in the wake of the decision in Pickles (n 30) that although there had been some doubt (following Mogul Steamship Co Ltd v McGregor, Gow and Co [1892] AC 25) whether English law embraced the idea that malice could ground liability, he conceded after the decision in Pickles that no such doubt could henceforth be maintained. For discussion of Pollock's earlier commitment to what in the USA is called the prima facie tort doctrine, and his gradual acceptance that that doctrine did not form part of English Law, see N Duxbury, Frederick Pollack and the English Juristic Tradition (Oxford 2004) 271-279. 
whether the particular defence is available. ${ }^{34}$ That malice is not a general touchstone of liability in defamation is clear from Lord Bramwell's well-known remark that, "[a] man may be the publisher of a libel without a particle of malice or improper motive". ${ }^{35}$

A final tort in which the role of malice needs to be cleared up is that of malicious falsehood. In this tort malice does not mean spite, ill-will or even anything close to that. Rather, mere knowledge of, or recklessness as to, the falsity of the statement in question will suffice. ${ }^{36}$ Put more simply, malicious falsehood is concerned with dishonest misrepresentations rather than with defendants actuated by malice in the accepted sense. The tort is a closer companion of deceit and passing off than the four torts with which this article is concerned. Much of the confusion generated by the label "malicious falsehood" could be avoided if its alternative name, "injurious falsehood", were generally preferred. ${ }^{37}$

What this section has suggested is that malice (or some synonym for malice) is only plausibly an essential ingredient in the four torts identified above. ${ }^{38}$ The qualifier "plausibly" is needed because whether malice is in truth required in all of them depends on whether various pivotal phrases that one finds used in certain cases deserve to be treated as synonyms for malice. It is to this awkward question of teasing out the precise legal connotation of malice that we must now turn.

\section{Unearthing a Unitary Conception of Malice}

\section{A. The Theoretical Importance of a Unitary Conception}

Attempts at discovering a precise meaning of malice (qua touchstone of liability) in tort law have been thin on the ground over the last half century or so. ${ }^{39}$ Quite why this should be the case is unclear given that malice has been central to the disposition of many tort cases over several centuries. ${ }^{40}$

Early studies reveal that its legal meaning has varied very considerably, not just between torts, but also within a single tort, over time, from one case to the next. Indeed, according to Fridman, there has been such variable use of the term malice that "there must be judicial authority for any or almost any meaning that a writer wishes to attribute to the word". And mindful of this, Lord Mance in Willers

34 See Toogood v Spyring (1834) 1 CM \& R 181, 193 (qualified privilege); Defamation Act 2013, s 3 (honest comment).

35 Abrath v NE Ry (1886) 11 App Cas 247, 253.

36 Wilts United Dairies v Robinson [1957] RPC 200, 226-7 (Stable J). The Court of Appeal affirmed Stable J's decision and held that even a misrepresentation by conduct would suffice: Wilts United Dairies v Robinson [1958] RPC 99, 101 (Morris LJ).

${ }^{37}$ Salmond used the label "injurious falsehood" first: J Salmond, Torts (London 1907) 149. Others who continue to use it include A Beever, A Theory of Tort Liability (Oxford 2016) 171; P Cane, "Mens Rea in Tort Law" (2000) 20 OJLS 533, 539; Newark (n 15) 376; Prosser (n 15).

${ }^{38}$ Cf Beever (n 37) 132-4.

${ }^{39}$ In the present era, the most sustained treatment belongs to Arthur Ripstein. However, he is not specifically concerned to discover a single meaning of malice across several torts. He attends mainly to the role of malice in private nuisance. He argues principally that malice should be understood in terms of D's means and not D's ends: see Ripstein (n 2) 168-9. There is also some treatment of malice in J Finnis, "Intention in Tort Law" in DG Owen (ed), Philosophical Foundations of Tort Law (Oxford 1995).

40 As Lord Toulson observed in Willers ((n 12), [52]): “over the last 400 years there has been a volume of case law about malice". His speech offers a sizeable trawl of the malicious prosecution and abuse of process cases going back to the seventeenth century cases of Waterer $v$ Freeman (1618) Hob 266 and Atwood v Monger (1653) Style 378.

${ }^{41}$ GHL Fridman, "Malice in the Law of Torts" (1958) 21 MLR 484, 484. See also WE Ormsby, "Malice in the Law of Torts" (1892) 8 LQR 140; LC Krauthoff, "Malice as an Ingredient of a Civil Cause of Action" (1898) 21 Annual Report of the American Bar Association 335. 
treated the historic slipperiness of the concept as a reason not to extend the tort of malicious prosecution to the malicious pursuit of civil proceedings. ${ }^{42}$

Fridman, however, overstated the true position. The relevant case law reveals just four main conceptions of malice that have been used in the torts that concern us. ${ }^{43}$ But there the simplification of our task ends, for there are not four separate conceptions, each one applying uniquely to its own tort. Rather, there are four different conceptions in total, but multiple meanings of malice can sometimes be found at work within any one of our four key torts: while some cases of malicious prosecution suggest that malice means $x$, there are others that suggest it means $y$.

Now, it is clearly unsatisfactory for there to be no settled concept of malice within any single tort. The rule of law principle that like cases must be treated alike requires as much. So, as Neil MacCormick explains:

however desirable on consequentialist grounds a given ruling might be, it may not be adopted if it is contradictory of some ... [extant] binding rule ... [Thus] the requirement for consistency would require rejection of an otherwise attractive ruling on the ground of its irresoluble conflict with [an established rule]. ${ }^{44}$

Put more concretely, whatever the appeal of giving malice meaning $x$ within a given case of, say, malicious prosecution, there is no legitimate warrant for adopting this meaning when malice has already been given meaning $y$ in some previous case that has precedential weight.

The desirability of a unitary conception of malice does not end there, however, for there is an equally strong case for a single meaning of malice to be employed across all of the four torts in which it is an ingredient of liability. The argument here is not based on the need for consistency in adjudication, but, instead, upon the value of the law's coherence. As MacCormick again explains:

'Coherence' is intended in a looser sense [than consistency]. One can imagine a random set of norms none of which contradict each other but which taken together involve the pursuit of no intelligible value or policy. A trivial example: a rule that all yellow motor cars must observe a maximum speed limit of $20 \ldots$ does not contradict or logically conflict with a rule that all red, green, or blue motor cars must observe ... a maximum of $70 \ldots$ But on the face of it, no principled reason can be given for such a difference. 45

It is, of course, possible for malice to be given one meaning within, say, the tort of lawful means conspiracy and another meaning within the tort of malicious prosecution without any inconsistency. In lawful means conspiracy, Rule $A$ might require the claimant to prove malice meaning $x$. By contrast, and quite separately, in malicious prosecution Rule $B$ might require the claimant to show malice meaning $y$. But incoherence would follow. Although strictly speaking Rule $A$ does not contradict Rule $B$, the coexistence of these two rules serves to distort a certain core principle or value of the wider legal system. In the same way that variable speed limits based on car colour would fail harmoniously to subserve a common value (such as environmental protection, or road safety), so, too, would two different rules on malice cause confusion as to the type of conduct that the law is seeking to address.

Such confusion can be avoided if a unitary meaning of malice is applied across the board. To see why, let us assume for now - though this conception will be defended later - that that what links our

42 Willers (n 12) [137]-[140].

43 These, discussed fully in Section III B below, are malice qua (i) spite or ill-will; (ii) intention to do a wrongful and harmful act; (iii) acting without just (or reasonable and probable) cause; (iv) acting with improper motives.

${ }^{44}$ N MacCormick, Legal Reasoning and Legal Theory (Oxford 1978) 106.

45 ibid. 
four torts is the abuse of public powers. ${ }^{46}$ In each tort, the claimant would have to show malicious abuse of such a power. But if malicious were to mean spiteful in one tort, while some lesser notion of malice animated another, we would be left wondering what common value was subserved by making malice a touchstone of liability in these torts. There ought to be a common reason for making the malicious doing of $M$ a tort and for making the malicious doing of $N$ a tort where both $M$ and $N$ are abuses of public power. Yet such a value would be obscured if different conceptions of a malicious abuse of public power were simultaneously in play. The law would appear not just incoherent, but also arbitrary. ${ }^{47}$

Suppose for example, that a public officer were, on a single occasion, to abuse his powers so as to create the possibility of being sued either for abuse of process or for misfeasance in a public office. In such a case, the law would invite ridicule if the single act in question could be described as malicious for the purposes of the former, but not for the latter. The problem of incoherence/arbitrariness is a serious one, and Lord Sumption was rightly attentive to it in his dissenting speech in Willers. ${ }^{48}$

In short, there is a strong theoretical case - grounded in a concern for consistency and coherence in the law - for having a unitary conception of malice both within and across all of the torts in which it forms a touchstone of liability. So, bearing in mind the present ambition to provide a better understanding of these torts, we must now endeavour to unearth whether any such unitary conception of malice can be found. If it can, we will be well on our way to discovering their raison d'etre, and will also have to hand an obvious response for those who consider these torts to be anomalous or sui generis causes of action.

\section{B. The Interpretative Case for a Unitary Conception of Malice}

As noted already, four main conceptions of malice have appeared over the years in the case law associated with the torts considered in this article. According to the most obvious of these conceptions, malice is (as in common parlance) a synonym for spite or ill-will. There are certainly some early cases in which this meaning was applied. In Hicks $v$ Faulkner - a malicious prosecution case - it was suggested that " $t$ t] he malice necessary to be established is ... malice in fact - malus animus indicating that the party was actuated by spite or ill-will towards an individual". " Since then, however, the courts have made clear on many other occasions that malice is not to be construed so narrowly. Indeed, modern cases seem universally to reject this construction. Among them is the recent Privy Council decision in Crawford Adjustors v Sagicor General Insurance. ${ }^{50}$ Given the modern tendency not to adopt the common parlance interpretation, ${ }^{51}$ it seems appropriate to dismiss the idea that, within in our four torts, malice means spite or ill-will.

A second meaning of malice was that adopted by Bowen LJ in the landmark case of Mogul Steamship Co Ltd v McGregor, Gow \& Others, namely, that it "means and implies an intention to do an

\footnotetext{
46 For three accounts that come close to this, see EJ Weinrib, “Two Conceptions of Remedies" in CEF Rickett (ed), Justifying Private Law Remedies (Oxford 2008) 29; Beever (n 37) 173; Ripstein (n 2) 182-3.

${ }_{47}$ Beever, more charitably, calls the problem one of limited rationality: A Beever, Rediscovering the Law of Negligence (Oxford 2007) 22.

48 Willers (n 12) [178].

49 (1881) 8 QBD 167, 175. An additional construction, though, was malice as "indirect or improper motives": ibid.

50 [2013] UKPC 17, [72] (Lord Wilson): "the concept extends beyond spite": ibid [72].

51 McCardie J summed things up neatly observing: "the jurist ... enlarged the layman's notion of malice": Pratt v BMA [1919] $1 \mathrm{~KB} 244,275-6$. Other judges keen to distinguish the legal and everyday meanings of malice include Bowen LJ (" $[\mathrm{t}]$ he terms 'maliciously', 'wrongfully', and 'injure' are words all of which have accurate meanings, well known to the law, but which also have a popular and less precise signification”: Mogul Steamship Co Ltd v McGregor, Gow \& Others (1889) 23 QBD 598, 612) and Bayley J (distinguishing the legal meaning of malice and "[m]alice, in common acceptation": Bromage v Prosser (1825) 4 B \& C 247, 255).
} 
act that is wrongful to the detriment of another" ${ }^{52}$ It is a formulation that has its origins in the tort of malicious falsehood, and at least one attempt has been made to apply it to the tort of abuse of process. That attempt failed, ${ }^{53}$ and the Supreme Court has since also shown itself unwilling to adopt this meaning in the context of malicious prosecution. ${ }^{54}$ Since there is no evidence that it has ever been considered relevant to the other two torts with which we are concerned - and since malice thus understood is in any case redundant as a touchstone of liability ${ }^{55}$ - we can also dismiss this construction of malice.

A third contender for the unitary meaning of malice is that of acting without just (or reasonable and probable) cause. The idea that acting in this way could be synonymous with malice might be thought to follow from Parke $\mathrm{J}$ having said in Mitchell v Jenkins that "in every action for a malicious prosecution ... when there is no reasonable or probable cause, it is for the jury to infer malice from the facts proved". ${ }^{56}$ But any such notion that the two ideas should be treated as co-terminous must be rejected for at least four reasons. To begin with, Parke J's words are directed to the matter of how evidence is acquired rather than to a particular legal concept. ${ }^{57}$ Secondly, the Supreme Court was aware of this third possible interpretation in Willers yet steadfastly refused to accept it. Lord Toulson stated emphatically that "the requirements of absence of reasonable and probable cause and malice are separate requirements although they may be entwined". ${ }^{8}$ Thirdly, malice is a matter that relates to the mindset of the defendant whereas a lack of reasonable cause is an empirical fact in the world. Fourthly, although the two issues often overlap, it is important to realise that they can also come apart quite markedly. For example, as Scrutton LJ observed in Greers Ltd v Pearman \& Corder Ltd, an "[h]onest belief in an unfounded claim is not malice" 59 and yet the case would be one with no reasonable cause.

The fourth possible meaning of malice - namely, malice construed as an improper or bad motive - is altogether more promising in terms of providing our golden thread. Indeed, I would suggest that it is the conception of malice that is either overtly or impliedly used in each the four torts with which we are concerned.

In lawful means conspiracy, the courts overtly anchor a defendant's liability to a bad motive. ${ }^{60}$ (And here I adopt the accepted view of motive as "the reason why one engages in the conduct" in question.) Talk of bad motive appears repeatedly in the various opinions delivered in the landmark case of Quinn v Leathem; ${ }^{2}$ and it is clear from the way that the terms "bad motive" and "malice" were used interchangeably that in that case that they were seen as synonyms. Lord Shand, for example, stated generally that "combination ... in pursuit merely of a malicious purpose to injure another, would be clearly unlawful" "before going on to explain that such malicious purposes were to be discovered

\footnotetext{
52 Above (n 51), 612.

${ }^{53}$ Jacob v Vockrodt [2007] BPIR 1568.

54 Willers (n 12) [55]. Lord Toulson specifically pointed out that it had been used in "the early cases" and referred to it as "the nineteenth century understanding of the word malicious": ibid.

55 The redundancy inheres in the fact that, in this "malice in law" construction, the malice adds nothing to the question of liability: it is merely evidence of, or synonymous with, intent to commit an act that is already wrongful. It could, however, be relevant to the question of whether aggravated damages should be awarded.

${ }^{56}$ In similar vein, see Waterer v Freeman (1792) 80 ER 352, 352; Wren v Weild (1869) LR 4 QB 730, 736.

57 On the idea that inferences ordinarily pertain to factual matters rather than have any bearing on conceptually tricky legal ingredients, see $\mathrm{R} v$ Woollin [1999] 1 AC 82 (intent in criminal law only to be inferred exceptionally: from D's foresight of a virtually certain outcome).

58 [2016] 3 WLR 477 [54]. See also Glinski v McIvor [1962] AC 726, 765.

59 (1922) 3 RPC 406, 417. Equally, "if there be reasonable or probable cause, no malice, however distinctly proved, will make the defendant liable": Mitchell v Jenkins (1833) 5 B \& Ad 588, 594.

${ }^{60}$ In cases of mixed motives, it is D's predominant motive that must meet this description: Crofter (n 19$)$ at 445.

${ }^{61}$ Cane (n 37) 539.

62 [1901] AC 495.

63 ibid 512.
} 
in the defendant's improper motives. ${ }^{64}$ Equally, although elsewhere in his speech Lord Halsbury spoke a good deal about the defendant's motives, he was adamant from the outset that the action for lawful means conspiracy turned, ultimately, on whether the defendants had acted "in pursuance of a conspiracy formed among them .... and that all this was done with malice". ${ }^{65}$ Lord Lindley, too, spoke of acting "maliciously in the sense of proceeding from a bad motive". ${ }^{66}$

In the later House of Lords' case of Crofter Hand Woven Harris Tweed Company Ltd $v$ Veitch, Lord Porter likewise aligned malice with motive saying that there could be liability for lawful means conspiracy "if one of the parties had no purpose but to vent his own vindictive spite and if the other knew of and countenanced that purpose by giving his assistance to the malicious acts of the first". ${ }^{67}$ Viscount Maugham, too, was clear that the problem of mixed motives in lawful means conspiracy cases requires a court to weigh the fact that "what the defendants had done was done with malice" against the observation that "one at least of the motives actuating the defendant was the benefit [to themselves or others]". ${ }^{68}$ All in all, then, despite some vacillation in the cases between talk of "malice", "bad faith", "bad motive" and "improper purposes", it seems tolerably clear that the leading cases bear out Cane's general observation that, "[i]n tort law, bad motives are referred to as 'malice". ${ }^{69}$

In the tort of abuse of process, malice again appears in the guise of an improper purpose (or bad motive) requirement. In Grainger $v$ Hill, ${ }^{70}$ where the defendant abused the legal process in order to gain possession of property to which he knew he was not entitled, Bosanquet $J$ set out the basis of the action. He said that the tort is committed where "the process [of the court] was enforced for an ulterior purpose; to obtain property by duress to which the Defendants had no right" and that, unlike malicious prosecution, "the action is not for maliciously putting process in force, but for maliciously abusing the process of the court". ${ }^{71}$ In similar vein, Tindall CJ said that the tort could be invoked where "the process of the law has been abused, to effect an object not within the scope of the process". ${ }^{72}$ So, as with lawful means conspiracy, the idea of malice qua improper motive clearly undergirds the tort of abuse of process.

In the misfeasance tort, the role of improper motive was spelled out in the first few pages of Lord Steyn's leading speech in the Three Rivers case. Before listing the exact ingredients of the tort, he made clear, quoting Winfield \& Jolowicz, on Tort, that "the tort of misfeasance in a public office is an exception to 'the general rule that ... if conduct is lawful apart from motive, a bad motive will not make ... [one] liable". ${ }^{73}$ He then set out the two versions of the tort that we noted earlier. In relation to the first of these, the idea that malice should be understood in terms of improper motive could scarcely have been expressed more clearly. Lord Steyn specifically dubbed it the "targeted malice" version before explaining its operation in terms of "the exercise of public power for an improper or ulterior motive". 74 That the second version also requires malice qua bad faith (and therefore improper motive ${ }^{75}$ ) was also made clear:

\footnotetext{
${ }^{64}$ He said of the defendants in Quinn that " $[\mathrm{t}]$ heir acts were wrongful and malicious ... [since] they acted by conspiracy... for the sole purpose of injuring the plaintiff in his trade": ibid 515.

65 ibid 506.

66 ibid 533.

${ }^{67}$ ibid 495.

68 ibid 452.

${ }^{69}$ Cane (n 37) 539.

70 (1838) 4 Bing NC 212.

71 ibid 224.

72 ibid 221.

73 Three Rivers District Council v Governor and Co of the Bank of England (No 3) [2003] 2 AC 1, 190.

74 ibid 191.

${ }^{75}$ For Lord Steyn's linking together bad faith and improper motive, see above (n 21).
} 
a public officer acts knowing that he has no power to do the act complained of and that the act will probably injure the plaintiff. It involves bad faith inasmuch as the public officer does not have an honest belief that his act is lawful. ${ }^{76}$

The malice in play here is not the targeted malice that animates the first version, but rather a kind of malice that Peter Cane has labelled "collateral malice". This collateral malice involves the defendant using a privilege or power "for some purpose other than that for which ... [it] is given". ${ }^{77}$ Any public officer who knowingly uses his powers for purposes other than those for which they were conferred cannot but be said to be acting in bad faith. ${ }^{78}$ And because her act has not the remotest colour of being used for a proper purpose, it may fairly also be described as malicious even though the officer bore the claimant no specific ill-will.

There is certainly weighty judicial support for the idea that acts falling within this second version of the tort should be regarded as malicious. In the Three Rivers case, in addition to Lord Steyn having said as much ${ }^{79}$ Lord Hutton also insisted that "the second limb of the tort is a species of malice" ${ }^{80}$ Only slightly more guardedly, Lord Clarke said in Willers that the second limb of the misfeasance tort is "close to the test of malice referred to in the wrongful arrest cases" ${ }^{81}$ Jurists, too, are on record as holding the same view. Donal Nolan, for example, says of this second version of the misfeasance tort that "conscious violation of the law to the prejudice of another" amounts to malice for legal purposes; ${ }^{82}$ while Jason Neyers has also argued that such acts are malicious insofar as the officer's "primary purpose is not one that officer, to his or her knowledge is entitled to have". 83

At the very least, equating bad faith in the misfeasance tort with malice qua improper motive ensures terminological consistency with lawful means conspiracy where, as noted earlier, precisely that meaning is ascribed to bad faith. ${ }^{84}$

The idea that improper motive is an appropriate way to understand malice in the tort of malicious prosecution is also readily shown. In Crawford, the defendant caused certain insurers in the Cayman Islands to sue the claimant for deceit and conspiracy to defraud. He did so with the express intention of driving the claimant out of business and ruining him professionally. When the case reached the Privy Council, Lord Kerr made the following observation:

A good working definition of what is required for proof of malice in the criminal context [runs as follows]: ... "to constitute malice, the dominant purpose of the prosecutor must be a purpose other than the proper invocation of the criminal law - an 'illegitimate' or oblique motive". That improper purpose must be the sole or dominant purpose actuating the prosecutor. ${ }^{85}$

He then added that "[ $\mathrm{t}]$ here is no reason that proof of malice in the civil context should be any less stringent". ${ }^{86}$ In Willers, Lord Toulson put it slightly differently. He said: "the claimant must prove ...

${ }^{76}[2003] 2$ AC 1, 191.

${ }_{77}$ Cane (n 37) 539.

${ }^{78}$ In Three Rivers, Lord Steyn was clear that all public law powers can only legitimately be exercised for the public good: [2003] 2 AC 1190.

${ }^{79}$ See above (n 21).

${ }^{80}$ Three Rivers (n 73) 224.

${ }^{81}$ Willers (n 12) 503.

${ }^{82}$ D Nolan, "A Public Law Tort: Understanding Misfeasance in a Public Office" in K Barker et al (eds), Private Law and Power (Oxford 2017) 197 (citing Ferguson v Kinnoull (1842) 9 Cl \& F 251, 321).

83 JW Neyers, "Explaining the Inexplicable? Four Manifestations of Abuse of Rights in English Law" in Nolan and Robertson (n 3) 320.

${ }^{84}$ Crofter (n 19) at 483 and 495 (Lords Porter and Simon).

85 [2013] UKPC 17 [109].

86 ibid [110]. 
that the defendant did not have a bona fide reason to bring the proceedings" ${ }^{87}$ This of course raises the question of what is meant by bringing an action without a bona fide purpose. And on that question his Lordship thought an action could be so regarded if the defendant were to "bring the proceedings ... to secure some extraneous benefit to which he has no colour of right ${ }^{88}$ The talk of purposes, of course, makes clear that, like Lord Kerr in Crawford, Lord Toulson was ultimately concerned to attach liability to those who institute civil proceedings with an improper motive. And in so doing, he was bringing the meaning of malice in this tort into line with a number of earlier cases in which malice had been thus conceived. For example, in Hall v Semple (where the claimant alleged that the defendant had maliciously caused him to be detained in custody as a person of unsound mind), Crompton $J$ held that ' $[\mathrm{m}]$ alice does not mean merely spite, but any improper motive. ${ }^{89}$

This section has explained that, although four different meanings have malice have appeared at various times (and with varying degrees of regularity) in the case law associated with the torts with which this article is concerned, only one such conception - malice qua bad or improper motives - can be seen at work in all four of those torts. It is by no means an obvious conception, and it also contrasts markedly with the meaning of malice in the criminal law setting where, historically, it featured prominently in the definition of various statutory crimes. ${ }^{90}$ Nonetheless, it is a meaning that we should accept. For not only is there weighty judicial support for equating malice with bad or improper motives in each of the four torts considered here, there is also a powerful theoretical case (based on coherence in the law) for so doing. Alternative constructions - such as malice qua spite - have for the most part been rejected by our most senior courts, and in any event (because they were never used in all four torts) these rival conceptions lack the capacity to unite the four torts in view in a way that renders the law coherent. What must now be considered is whether a plausible defence can be made in favour of treating malice as a touchstone of liability in tort.

\section{The Merits of Malice as an Ingredient of Liability}

Showing that malicious prosecution, abuse of process, the misfeasance tort and lawful means conspiracy all operate according to a shared conception malice clearly helps to rebuff claims that one or more of these torts is a sui generis cause of action (in the sense that they are unique). Having a common ingredient allows each of them to be seen as part of a quartet with a common thread rather than as an anomalous one-off. At the same time, however, identifying this commonality does nothing to insulate these torts from the complaint that they undermine the value of coherence in the law of torts generally. Mindful of this, we might ask how malice can ever be tolerated as an ingredient of tortious liability given what the House of Lords has said numerous times about malice not converting ostensibly lawful acts into unlawful ones. Even as a quartet, it is not obvious that we should regard the four torts in view as meritorious members of the tort law family. Any argument seeking to justify their existence must be made on independent grounds. The fact that one can advert to a number torts that share a common flaw does nothing to negate or ameliorate the fact that that flaw exists.

\footnotetext{
${ }^{87}$ [2016] 3 WLR 477 [56].

88 ibid [55].

${ }^{89}$ (1862) 3 F \& F 337, 357. For several other examples, see Fridman (n 41) 484-5.

90 A fair number of nineteenth century criminal law statutes required offences to be committed "maliciously"; and the Court of Criminal Appeal held that, "in any statutory definition of a crime 'malice' must be taken ... as requiring either (1) an actual intention to do the particular kind of harm that in fact was done, or (2) recklessness as to whether such harm should occur": R v Cunningham [1957] 2 QB 396, 399 (Byrne J). The requirement that certain assaults be committed maliciously still features, unamended, in various sections of the Offences Against the Person Act 1861.
} 


\section{A. Existing Arguments Concerning Malice as an Ingredient of Tortious Liability} "It is a general rule of our law", said Lord Herschell in Allen v Flood, "that an act prima facie lawful is not unlawful and actionable on account of the motive which dictated it". "This is probably the most frequently cited judicial statement against malice being treated as a touchstone of liability in tort. But it is not the only one. In the earlier case of Mayor of Bradford $v$ Pickles, Lord Watson opined that "the existence of a bad motive, in the case of an act which is not in itself illegal, will not convert that act into a civil wrong". ${ }^{22}$ These powerful statements, made by our most senior judges, are seemingly inconsistent with our four particular torts, all of which make malice an essential touchstone of liability. ${ }^{93}$ Yet resolving the apparent inconsistency is not impossible.

To begin with, we may note that the law is in a constant process of development. Such ongoing development allows for what may at first appear to be blanket rules to give way to exceptions here and there. For example, the decision in Hedley Byrne \& Co Ltd v Heller $r^{44}$ marked an end to the idea that there could be no liability for misstatements outside the law of contract and the tort of deceit. In Derry $v$ Peek, Lord Bramwell had laid down the apparently blanket rule that, where misstatements were concerned, "[t]o found an action for damages there must be a contract and breach, or fraud". ${ }^{55}$ But Lord Reid, in his leading speech in Hedley Byrne, made clear that this should not be treated as an absolute rule. He said, clearly marking his departure from the received view, that

[i]t must now be taken that Derry $v$ Peek did not establish any universal rule that in the absence of contract an innocent but negligent misrepresentation cannot give rise to an action... We cannot, therefore, now accept as accurate the numerous statements to that effect in cases between 1889 and 1914, and we must now determine the extent of the exceptions to that rule. ${ }^{96}$

If we look again at what Lord Herschell said in Allen, we can see that his dictum also plainly allowed for exceptions. Notice how he was careful to preface what he said about motive's inability to render unlawful what would otherwise be lawful. He made absolutely clear the fact that he was enunciating only a "general rule"; and mere general rules always allow for exceptions. This, then, is how we may view the four torts considered in this article in that, in a departure from Lord Herschell's general rule, they each make improper motives an essential ingredient of liability. ${ }^{97}$ Added to this is a third reason to treat with caution the idea that either Allen or Pickles laid down a blanket rule against tort liability being anchored to malice. It exists in the form of a broad reminder issued by Lord Halsbury in Quinn $v$ Leathem about the inherent limits of rules of law, even when they are expressed in general terms. He warned that:

[E]very judgment must be read as applicable to the particular facts proved, or assumed to be proved, since the generality of the expressions which may be found there are not intended to be expositions

\footnotetext{
91 [1898] AC 1, 124. To like effect, Lord Davey said, "it seems to be an argument in a circle to say that an act not otherwise wrongful becomes so if malicious": ibid 171. See also ibid 92 (Lord Watson) and Lonrho Ltd v Shell Petroleum (No 2) [1982] AC 173, 188.

92 [1895] AC 587, 592. He effectively reiterated the point in Allen v Flood [1898] AC 1, 92.

${ }^{93}$ Beever (n 2) 132-134 attempts such reconciliation. But his argument is undermined by his seeking to rely two different conceptions of malice that can supposedly be found in the case law. This approach is interpretively problematic since these putatively different meanings are drawn from cases that cite a common source.

94 [1964] AC 465.

95 (1889) 14 App Cas 337, 347.

${ }^{96}$ [1964] AC 465, 484. Similar doubts about Derry v Peek having established such a rule were expressed by Lord Devlin: ibid, 516 .

${ }^{97}$ It might also be noted that Lord Herschell's general rule was itself a dilution of the rule cast in seemingly absolute terms by Lord Watson in the Pickles case.
} 
of the whole law, but governed and qualified by the particular facts of the case in which such expressions are found..$^{8}$

A fourth caveat belongs to John Finnis who regards the dicta in Allen $v$ Flood and Bradford $v$ Pickles just quoted as "gratuitous". ${ }^{99}$ By this he means that they comprise judicial utterances that are conspicuously without proper foundations: they neither reveal, nor purport to be grounded in, any relevant precedents. In this he is assuredly right. What was said about the legal significance of malice in both of those cases was mere affirmation. Accordingly, we may justifiably question the extent to which they ever constituted a robust statement of the law.

There is however a second objection to malice being treated as an ingredient of tort liability. It is based on pragmatic considerations. For all that Bowen LJ may have correctly observed that "the state of a man's mind is as much a fact as the state of his digestion", ${ }^{100}$ it is a fact, nonetheless, the ascertainment of which is fraught with difficulty. It is obviously harder to establish what a person is thinking than it is to assess the functionality of his gastric system. Thus, the objection goes, from the perspective of practical justice, requiring a claimant to prove the defendant's motive places too much of a strain on the justice system, since it "plunges the courts into all sorts of difficulty....ascertaining people's motives". ${ }^{101}$ But is this right? For a start, the criminal law almost invariably requires proof of intent; so it might well be asked why proof of malice (on the balance of probabilities) in a civil law case is likely to create any such problem when proof of intent (beyond all reasonable doubt) in criminal law does not do so. Secondly, it is demonstrably the case that the four torts in which malice is a touchstone of liability are far from routinely invoked. Thus, although it is true that ascertaining a defendant's motive can be problematic, the amount of work these torts generate for the courts must not be overstated. Thirdly, there is no evidence from those cases in which aggravated damages are sought (and in which motive is again a salient factor) that the courts, on such occasions, are placed under unmanageable strain. And fourthly, even if the need to prove malice does produce more work for the courts, it is nonetheless true, as Lord Toulson pointed out in Willers that "[e]xpenditure of court time is sometimes the public price of justice". ${ }^{102}$

Yet another objection to making malice an independent touchstone of liability is that its role in tort has already been settled: as a mere aggravating factor. A tortious act committed with malice is the type of act that is likely to infringe the claimant's dignitary interest and thereby malice can be seen to ground an award of aggravated damages. ${ }^{103}$ This argument, however, suffers from the false assumption that a given factor proved in evidence can only have one function. Proof of intent, for example, might serve to ground both the existence of liability for battery and the ruling out of a plea of contributory negligence in such a case. ${ }^{104}$

Changing tack, we might seek to distil a defence of the role of malice in the ascription of liability from the prima facie tort doctrine which has a firm foothold in the USA. According to this doctrine, any act that intentionally causes harm or is manifestly likely to cause it (and does so) is deemed to be

\footnotetext{
98 [1901] AC 495, 506.

${ }^{99}$ Finnis (n 39) 238.

100 Edgington v Fitzmaurice (1885) 29 Ch 459, 483.

101 NJ McBride and RM Bagshaw (London 2018) 659.

102 Willers (n 12) [58].

103 According to Lord Devlin in the leading case on such damages "in cases where the damages are at large, the jury (or the judge if the award is left to him) can take into account the motives and conduct of the defendant where they aggravate the injury done to the plaintiff... [For] the wrong may be such as to injure the plaintiffs proper feelings of dignity or pride" and "[t]hese are matters which the jury can take into account in assessing the appropriate compensation": Rookes $v$ Barnard [1964] 1129, 1221 For other such dicta, see J Murphy, "The Nature and Domain of Aggravated Damages" [2010] CLJ 353.

104 Pritchard v Co-operative Group Ltd [2012] QB 320, [61]-[62].
} 
tortious in the absence of just cause. And since malicious acts (at least in the targeted sense) are highly likely to cause harm, they may fairly be deemed tortious by virtue of their augmented propensity to cause harm. ${ }^{105}$ There is, however, an obvious snag here: the fact that the prima facie tort doctrine is not part of English law. Thus, although this doctrine sheds some light on what may be thought normatively appealing about our four torts, it cannot, on the current state of English law, be invoked as a sound juridical justification for their existence.

The exact same objection can be raised against another defence of malice (qua touchstone of liability) offered by John Finnis. He argues that, as a philosophical or moral matter, "[o]ne's conduct will be right only if both one's means and one's end(s) are right". ${ }^{106}$ But however much philosophy is on his side, the law as it stands is not.

None of the arguments considered above offer a convincing case either for or against making malice a touchstone of liability. The cautionary notes sounded by Finnis and by Lord Halsbury cause us to doubt whether what was said in Allen $v$ Flood was sound in the first place (even if it was in fact intended as blanket prohibition on the use of malice as an ingredient of tortious liability). Equally, worries concerning the evidential burden associated with the need to prove malice seem unconvincing when comparisons with the criminal law and the law on aggravated damages are borne in mind. Thirdly, the view that malice should be treated as an exclusively aggravating factor rests upon an assumption that is easily falsified. In the opposite direction, the prima facie tort doctrine only has a toehold in the USA, and Finnis' desire to make malice a touchstone of liability has only philosophy (not precedent) to ground it.

If malice is ever to be justified (or ruled out) as an ingredient of tortious liability, we must look elsewhere for the reason why.

\section{B. An Alternative Argument}

The best argument that can be made in support of making malice an ingredient of liability in our four torts is that it enables them to be used to address abuses of public (or, at least quasi-public) powers. In saying this, I must now explain what I mean by public power. Though nuanced differences exist between Hartian and Hofeldian conceptions of a power, ${ }^{107}$ both accounts accept that powers (as a general matter) involve an ability recognised by law to change the legal position of another. But whereas private powers include such things as the ability to sell one's chattels, or establish a trust, or make a will, public powers are either those that are held exclusively by public officials or institutions ${ }^{108}$ or those that are held by private individuals but pertain to the engagement of public officials or institutions (for example, by commencing legal proceedings). ${ }^{109}$ It is my submission that each of the

105 The increased probability stems from the fact that "the harm complained of was not only foreseen but intended": OW Holmes, "Privilege, Malice and Intent" (1894) 8 Harv L Rev 1, 6.

106 Finnis (n 39) 238.

107 See A Halpin, “The Concept of a Legal Power" (1996) 16 OJLS 129.

108 This is the conception of a public power adopted in K Barker, "Public Power, Discretion and the Duty of Care" in K Barker et al (eds), Private Law and Power (Oxford 2016) 207: "One of the key features of a public body ... is that it is imbued with statutory powers that private individuals lack".

109 As explained more fully below, I consider the freedom of association that is integral to the tort of lawful means conspiracy a quasi-public power because the freedom involved is readily conceived in terms of a constitutional freedom to associate for communitarian purposes. 
four torts with which this article is concerned can be understood in terms of the abuse of such powers even though it is often said that an abuse of rights principle is alien to the common law. ${ }^{110}$

Since the misfeasance tort applies only to public officers who act in bad faith (and consequently for improper purposes), it can easily be seen in terms of an abuse of public power. ${ }^{111}$ Indeed, it offers the clearest example of all. For, as Arthur Ripstein observed, "[t]he defendant takes up what are supposed to be public powers and uses them against the plaintiff". ${ }^{112}$ The torts of abuse of process and malicious prosecution can also be described in terms of the abuse of a public power. They involve an abuse of the right to access the Queens's courts and the related legal machinery which animates both of these torts. ${ }^{113}$ Lord Steyn was clear in Gregory $v$ Portsmouth City Council that a highly material consideration in malicious prosecution cases is that "the defendant has abused the coercive powers of the state". ${ }^{114}$ His point is readily borne out by the fact that the vast majority of malicious prosecution cases are brought against the police.

Lawful means conspiracy can also be explained in terms of an abuse of power that has a public rather than private dimension to it. McBride and Bagshaw - who also take the view that the other three torts can be seen in something like the terms suggested here - are markedly more hesitant about regarding lawful means conspiracy this way. ${ }^{115}$ Presumably, their hesitancy is attributable to the less than obvious public law - or perhaps more accurately, "quasi-public law"

Jason Neyers, however, is anything but hesitant about so doing. For him, lawful means conspiracy is "a classic example of an abuse of rights." 117 Unfortunately, Neyers relies on affirmation rather than argumentation. He fails to make clear the right that he thinks is being abused in such cases. He merely states that this action exists because "conspirators are violating a claim-right created by the system of rights". ${ }^{118}$ He cites no case in support of this proposition but instead anchors his claim to Ernest Weinrib's engagement with the abuse of rights issue. According to Weinrib, there is conceptual space for an abuse of rights principle in tort law for the following reason:

$[\mathrm{P}]$ articipants in the system of rights are conceived as persons with a self-determining capacity for purposive action. Within this system each person pursues one's [sic] self-chosen purposes, subject only to the constraint that one's action be capable of coexisting with the purposiveness of others. This requires that one pursue one's purposes as ends that one is trying to achieve for oneself, not as an obstacle against what someone else is trying to achieve... Accordingly, it would be inconsistent with what is normatively presupposed in the system of rights to allow a right to operate in a way that

\footnotetext{
110 Bradford v Pickles [1985] AC 587 is often cited in support of this proposition. However, the case is best understood differently. It turned not on the absence of an abuse of rights principle, but on the absence of a right held by $\mathrm{C}$ to receive the water percolating under D's land: see McBride and Bagshaw (n 101) 450-51.

111 Jason Neyers certainly takes this view, but he mistakenly says that the purpose of this tort is to ensure a "prohibition on the targeted infliction of gratuitous harm": Neyers (n 83) 323. This characterisation of the misfeasance tort fails to capture many cases falling within version 2 for which targeted malice is not required.

112 Ripstein (n 2) 182. See also S Todd, "Liability in Tort of Public Bodies" in N Mullany and A Linden (eds), Torts Tomorrow: A Tribute to John Fleming (North Ryde 1996).

113 Martin v Watson [1996] AC 74, 88 (malicious prosecution); Hanrahan v Ainsworth [1990] 22 NSWLR 73, 120 (abuse of process). That access to the Queen's courts is a constitutional right was made clear in Bremer Vulkan Schiffbau und Maschinenfabrik v South India Shipping [1981] AC 909.

114 [2000] 1 AC 419, 426. See also Cranford (n 3) [134]-[135] (Lord Sumption).

115 McBride and Bagshaw (n 101) 675.

116 The term belongs to McBride and Bagshaw. They too suggest that malice prosecution, abuse of process and the misfeasance tort share the feature of an abuse of "public powers or quasi-public powers": ibid (italics in the original). The fail, however, to explain what they mean by the key term "public powers".

${ }^{117}$ Neyers (n 83) 323.

118 ibid, 324.
} 
would harm another without promoting (in the language of the civilians) a "serious and legitimate interest" of the right holder. ${ }^{119}$

This analysis, however, is irrelevant to the claim made by Neyers. He, recall, thinks that the tort is about "conspirators violating a claim-right" held by the claimant. ${ }^{120}$ But the passage just cited is concerned with abuses of rights held by defendants to pursue their self-chosen purposes. If, like Neyers, we resort to Hohfeldian terminology, then the "right" with which Weinrib is concerned is a "liberty" not a "claim-right". Neyers' claim is therefore baseless. Furthermore, even if he tried to rework his reliance on Weinrib - placing weight on the abuse of a Hohfeldian liberty - he would still be ensnared by another major problem: the fact that such Kantian analysis of what grounds lawful means conspiracy $^{121}$ is entirely absent from the relevant cases. This is significant because, as Scott Hershovitz notes, it is true that "judges sometimes grasp for principles they can't quite articulate. But for the most part, they are pretty good at saying what they mean, and the reasons they marshal in their opinions are in fact the grounds for their decisions". ${ }^{122}$

So are McBride and Bagshaw right, after all, to be hesitant about seeing lawful means conspiracy in a fashion akin to an abuse of rights? Perhaps not, for it is arguably the right to freedom of association that is abused in such cases. The relevant public law character of this right stems from the fact that freedom of association is enshrined in article 11 of the European Convention on Human Rights. By virtue of this fact, the corresponding duty binds only public bodies. Also, it has certainly been argued that, historically, this tort was best understood as an abuse of the very similar statutory right to associate and form trade unions. Fridman argued over half a century ago that, although "men have the legal power to combine, such power may only be exercised with a rightful and justified intention" and that "improper motive destroys the legality of the exercise of the power". ${ }^{123}$

Importantly, identifying that our four torts all involve abuses of public (or quasi-public) powers only takes us so far. Adverting to such a link falls a long way short of actually justifying their existence. And it also fails to explain why the malicious abuse of private powers does not similarly result in liability. What then is the justificatory magic in the abuse of public powers?

Perhaps the best answer to this question is that public powers are generally created for a specific purpose. So, whereas the private right of the defendant in Bradford $v$ Pickles to extract water percolating under his land could be said to exist for any number of purposes (such as making concrete, watering crops or giving it to animals), the same cannot be said of public powers which are created with a particular purpose in mind. It is therefore relatively easy, and arguably appropriate, to attach liability to the malicious abuse of those powers (especially when the best interpretation of malice seems to be that of acting for improper purposes). It is far easier to show that $\mathrm{D}$ has acted for an improper purpose when the purpose for which $\mathrm{D}$ is empowered to act is laid down in law.

With the misfeasance tort, any public officer in the frame for liability will have been granted certain powers in order to fulfil particular statutory functions. It seems apt, then, that when she acts inconsistently with the functions with which she has been entrusted, she should be held accountable. And when her breaking this trust in bad faith causes loss to private individuals, a respectable case can

\footnotetext{
119 Weinrib (n 46) 30 .

${ }^{120}$ Bizarrely, he states clearly that his ultimate aim is "to suggest that a rights-based account of the law can ... explain [various malice-based torts]”: Neyers (n 83) 310. Yet, rights-based accounts concentrate on C's (not D's) rights!

121 Weinrib offers his analysis as a basis for understanding all abuse of power torts. But it obviously cannot explain the misfeasance tort which attends to the abuse of public functions and not the abuse of self-chosen private pursuits.

122 S Hershovitz, "The Search for a Grand Unified Theory of Tort Law" (2017) 130 Harv L Rev 942, 969.

${ }^{123}$ Fridman (n 41) 497 (italics in the original).
} 
be made that her accountability should sound in tort. ${ }^{124}$ After all, as Aronsen observes: "while abuse of public power has long been the over-arching theme of judicial review... compensation is not in the suite of judicial review remedies". ${ }^{125}$

The sibling torts of abuse of process and malicious prosecution can equally be seen in terms of the abuse of a power that exists for a particular public purpose: the furtherance of the rule of law. Joseph Raz has certainly argued that access to justice is integral to the rule of law. ${ }^{126}$ However, our being invested with a right to such access has its limits: it is not a right that we can invoke for improper purposes. As was said by Issacs $\mathrm{J}$ in Varawa $v$ Howard Smith Co, much as we are entitled to engage the legal process in order to vindicate our rights, our right to access to justice must not to be used "merely as a stalking horse to coerce the defendant in some way entirely outside the ambit of the legal claim upon which the court is asked to adjudicate". ${ }^{127}$

The right to freedom of association, which is abused in the tort of lawful means conspiracy, also exists only for the pursuit of proper purposes. As Brownlee has explained, we overestimate the value of our freedom of association if we think it entails a general, "Hohfeldian moral permission to act". ${ }^{28}$ The better, and more accurate, view is that it confers only a circumscribed freedom to act: it gives us certain "rights of conduct" but these "do not immunise us from criticism when we exercise them to act wrongly". ${ }^{129}$ Put otherwise, the right to associative freedom carries only a right to act for legitimate purposes. No surprise, then, that article 11(1) of the European Convention on Human Rights should spell out that a citizen's right to freedom of association includes "the right to form and to join trade unions for the protection of his interests". Nor should it surprise us that the European Court of Human Rights has repeatedly stressed that the words in italics "are not redundant". ${ }^{130}$ The article 11 freedom is designed to be used only in the furtherance of proper purposes.

\section{Are the "Malice Torts" Ultimately Necessary?}

Notwithstanding the interpretive case that can mounted in defence of the four torts upon which this article centres, there remains one final matter that needs to be considered. It is whether there is any practical necessity for these torts. Some senior judges doubt whether malicious prosecution offers anything that is not already available via a different tort. ${ }^{131}$ Lawful means conspiracy and abuse of process are hardly ever successfully invoked, and the Law Commission recently considered whether the misfeasance tort should be abolished. So do these torts serve a distinctively useful purpose?

\section{A. Misfeasance in a Public Office}

In Administrative Redress: Public Bodies and the Citizen, the Law Commission reported that in its consultation paper, it had "suggested that this tort was not fulfilling any useful purpose ... [and] that

\footnotetext{
124 See Nolan (n 82) 183-6.

125 Mark Aronson, "Misfeasance in Public Office: Some Unfinished Business” (2016) 132 LQR 426, 427.

126 The rule of law, he argues, requires that "the courts should be easily accessible": J Raz, The Authority of Law, 2d ed (Oxford 2009) 217.

127 (1911) 13 CLR 35, 91 (Isaacs J).

128 K Brownlee, "Freedom of Association: It's not What You Think" (2015) 35 OJLS 267, 271.

129 ibid, 277.

130 See, eg, Wilson v United Kingdom (2002) 35 EHRR 20, [42]; Tum Haber Sen v Turkey (2008) 46 EHRR 19, [28]; Danilenkov $v$ Russia (2014) 58 EHRR 19, [121].

131 Gregory v Portsmouth City Council [2000] 1 AC 419, 432 (Lord Steyn)
} 
it should be abolished". ${ }^{132}$ It then acknowledged that many consultees disagreed pointing out that the misfeasance tort "played a necessary role as a marker for particularly opprobrious action by public officials ... [allowing] exemplary damages ... to reinforce the seriousness of the public body's wrongful actions". ${ }^{133}$ Combine this with the fact that the accountability of public officers is vital to our placing trust in (and thus enhancing the functional capacity of) public power, ${ }^{134}$ and it is clear the tort has an important practical role to play "attested to by the frequency with which it now appears in the law reports". 135

\section{B. Malicious prosecution}

In Willers, Lord Mance (in the minority) observed colourfully, that:

in an era when private prosecutions have largely disappeared, the tort of malicious prosecution of criminal proceedings is virtually extinct. To create a tort of malicious prosecution of civil proceedings might in these circumstances be thought to come close to necromancy". ${ }^{136}$

Lord Toulson disagreed entirely observing: "[it] is far from being a thing of the past". ${ }^{137}$ So who was right? Certainly, a Westlaw search reveals roughly 20 reported cases of this tort per year, the great majority of which involve defendants who have initiated criminal proceedings. But in addition to the enduring vitality of the tort in connection with criminal prosecutions is the practical usefulness of now being able to sue someone for the malicious pursuit of civil proceedings. In Gregory, Lord Steyn had opposed this development. He said that he was "not persuaded that the general extension of the tort to civil proceedings has been shown to be necessary if one takes into account the protection afforded by other related torts". ${ }^{138}$ He enumerated four such candidates: defamation, malicious falsehood, conspiracy, misfeasance in a public office. ${ }^{139}$ Yet in saying this he seemingly overlooked some important limitations of these other torts.

In defamation, a claimant may be stymied by the rule granting immunity to a witness in respect of evidence given in a court, even where the evidence is falsely and maliciously given. Malicious falsehood is narrow of scope: it applies only to statements made about the claimant or his property. Conspiracy requires a defendant to have acted in combination with a third person; while the misfeasance tort only applies to defendants who are public officers. It cannot safely be asserted, therefore, that malicious pursuit of civil proceedings is an unnecessary fifth wheel on the coach.

Equally, the rule that the loser pays costs in a civil case offers no guarantee that those who are maliciously sued will not suffer financially. Allowing an action for malicious pursuit of civil proceedings can address this problem. In Willers, the costs order was for $f 1.7 \mathrm{~m}$. Yet the actual costs incurred in defending the action came to $f 3.9 \mathrm{~m}$. Thanks to the existence of the tort of malicious prosecution, the claimant could recover the difference.

\footnotetext{
${ }^{132}$ Law Com No 322, 2010, [3.65].

133 ibid [3.66].

134 This argument belongs to Martin Loughlin: "constraints, which ensure that public power is wielded only for public purposes, bolster the confidence of the people in the integrity of government": M Loughlin, The Idea of Public Law (Oxford 2003 ) 85. For application of this thinking to the misfeasance tort, see Nolan (n 82) 183-6.

135 Nolan (n 82) 178.

136 Willers (n 12) [131].

137 ibid [43].

138 Gregory (n 114) 432.

139 ibid [431]-[432].
} 


\section{Abuse of Process}

Abuse of process has very limited practical utility. There is a distinct paucity of successful reported cases but this, by itself, does not mean that it is completely devoid of utility. In particular, unlike malicious prosecution, it can be relied upon even before the abusive proceedings have terminated in the claimant's favour. It can therefore be seen as a useful companion to its better known sibling, malicious prosecution. ${ }^{140}$ In any event, the fact that it is seldom successfully invoked is no reason to abolish it. It would be foolhardy to expend effort in discarding it when keeping it requires none, and it could on occasion - prove useful. Furthermore, it may have a useful deterrent effect on those who would seek to abuse the legal process. It catches those who employ proceedings they are entitled to bring, ${ }^{141}$ as a means of extorting something from the defendant to which they have no right. ${ }^{142}$ Of course, deterrence requires knowledge of such potential liability. But a good lawyer could be expected to warn her client of the dangers of abusing the legal process.

\section{Lawful Means Conspiracy}

Lawful means conspiracy is also seldom used in practice. Unlike the other three torts, however, it is difficult to see a specific practical function that it fulfils. It is unlikely to have any significant deterrent effect, since few, not trained in the law, would imagine that it can be tortious do certain things in combination that, if done alone, would be lawful. Equally, where conspirators have the predominant purpose of harming another, it normally will be the case that some other tort will be available for which the defendant could be liable as either an immediate or a joint tortfeasor.

On the other hand, there is a handful of reported cases in which this tort has proved useful. And as more than one Law Lord has noted, now that it has been around for so long it is "it is too late to do anything about it". ${ }^{143}$ It is "too well established to be discarded" ${ }^{144}$ It is hard, therefore to see why it can or should be abolished. ${ }^{145}$

\section{Conclusion}

There are four main torts in which malice is an essential ingredient of liability. Claims that they are anomalous or anachronistic actions are much too glibly made. If there were just one tort requiring proof of malice, or if they could be shown to have lapsed into desuetude, then such claims may have more traction. But, as we have seen, neither of these conditions obtain. At the same time, the idea that any of these torts can be characterised as sui generis can also be rebuffed by reference to the two features which link them together. They are all animated by a single conception of malice, and they all provide redress for abuses of public (or quasi-public) powers.

When a key ingredient - in our case, malice - bears the same meaning across a range of torts, the idea that this has occurred by accident or error is difficult to accept. Malice in all four torts can be understood in terms of acts done for improper purposes. This is significant since the second common

140 "[T] he two torts sprang from the same tree": Crawford (n 3) [62] (Lord Wilson).

141 Abuse of process does not, unlike malicious prosecution, require the absence of a reasonable cause: see Cranford (n 3) [62] (Lord Wilson).

142 The tort functions to target $\mathrm{X}$ where $\mathrm{X}$ uses proceedings he is entitled to initiate in order to coerce $\mathrm{Y}$ in some way that lies outside the proper ambit of the claim: Varawa v Howard Smith Co Ltd (1911) 13 CLR 35, 91 (Isaacs J).

${ }^{143}$ L Hoffmann, "The Rise and Fall of the Economic Torts" in S Degeling et al (eds), Torts in Commercial Law (Pyrmont, NSW 2011) 115.

144 Lonrho Ltd v Shell Petroleum Co Ltd (No 2) [1982] AC 173, 189 (Lord Diplock).

145 Cf Beever (n 37) 138-9. 
denominator relies on the fact that acts done for improper purposes can be cashed out in terms of an abuse of public (or quasi-public) power principle that helps justify these torts. Malicious prosecution and abuse of process both serve to curtail abuses of the power granted to all citizens to access the Queen's courts (where this power exists for the purpose of enhancing or ensuring the rule of law). The misfeasance tort addresses abuses of powers granted to public officers in order to enable them to fulfil specific public purposes laid down in statute. Lawful means conspiracy addresses the abuse of the basic right of freedom of association that we all have in order to allow us to pursue certain common purposes that are for the good (such as a worker's right "to form and to join trade unions for the protection of his interests"146).

For all that these torts operate according to a shared conception of malice, and for all that they can be justified by reference to their theoretical usefulness in relation to abuses of public powers, it remains true that they are relatively infrequently used. ${ }^{147}$ On the other hand, it by no means follows from this observation that we should discard them; for it is certainly wrong to think that the limited work that they do can always be done by some other cause of action. Equally, it would be wrong to afford them serious attention on the basis of their limited practical significance, for these torts have the potential to ground serious challenges to popular theories of tort law. The fact that they cannot easily be dismissed as anomalies or sui generis causes of action is a point that is seldom if ever appreciated by leading contemporary tort theorists. Yet these torts pose challenges for those theories insofar as they purport to offer grand, reductionist accounts of tort law. ${ }^{148}$

\footnotetext{
146 European Convention on Human Rights, Art 11(1).

147 The courts' ability to strike out vexatious litigation and the rule that losers pay costs reduce the incidence of malicious prosecution and abuse of process cases. Lawful means conspiracy cases are rare because there are few things that are done that are designed to cause loss to another that are prima facie lawful. The need to show malice combined with the fact that only public officers can be sued restricts the number misfeasance tort cases.

148 One form of challenge is based on tort law's remarkable heterogeneity (on which, see Murphy (n 5)); another is based on the fact that these torts have a distinctly public not private dimension, contrary to popular conceptions of tort law as exclusively a creature of private law (on which see, eg, J Murphy, "Misfeasance in a Public Office: A Tort Law Misfit" (2012) 32 OJLS 51).
} 